\title{
Impact of Gas Discoveries in the Eastern Mediterranean on Egypt-Israel Relations
}

Khaled Abdelhafez Fouad Sayed

Department of Political Sciences and International Relations

Institute of Social Sciences

Istanbul Aydin University

Tel: 00905346808264

Email: kabdelhafezsayed@ @stu.aydin.edu.tr Turkey

\section{Abstract}

The emergence of huge natural gas discoveries in the Eastern Mediterranean represents a significant factor in changing the map of cooperation and conflict in the region. The article's main hypothesis is that the gas discoveries in the Eastern Mediterranean have a significant geopolitical impact on the relations between Egypt and Israel. The article reviewed the hypothesis by examining the gas deal between Egypt and Israel and its consequences on the relations between both sides.

The article focuses on the geopolitical dimensions and economic feasibility of the Israeli gas deal on Egypt and the potential threats of the proposed Israeli East Med pipeline on Egypt.The article concludes that the massive quantities of natural gas reserves in the Eastern Mediterranean could act as important drivers for more partnerships and cooperation between Egypt and Israel and might lead to competition and conflicts between the two countries.

\section{KEYWORDS:Geopolitics, Cooperation, Conflict Introduction}

Relations between Egypt and Israel have a long and complicated history passed through various levels. Started with military disputes and wars in 1948, 1956, 1967, and 1973, then the period of establishing peace in Sadat era, then the period of security and economic relations in Mubarak era which is called the strategic peace (Aran \&Ginat 2014, p.580), then a few years of disturbance relations through the Egyptian revolution from 2011 to the mid of 2013 (Berti 2013), and finally the unprecedented levels of cooperation between the two countries after Sisi came to power. The emergence of sizable quantities of natural gas in the Eastern Mediterranean created a new geopolitical situation in the region (Dimou 2016), and in turn, has an impact on the relations between Egypt and Israel.

One of the major consequences of the emergence of gas discoveries in the Eastern Mediterranean was the gas deal between Egypt and Israel, where Israel would export 85.3 billion cubic meters of natural gas to Egypt over 15 years at a value of $\$ 19.5$ billion (Reuters 2019). Israeli Prime Minister Benjamin Netanyahu and Minister of Energy Yuval Steinitz could not hide their extreme happiness over Israel's export of natural gas to Egypt. Netanyahu described the day when the gas deal between
Egypt and Israel was concluded as a "joyous day" for Israel (Haaretz 2018). Almost two years after signing the deal, the Israeli Energy Minister in a video released in mid-January on Twitter described the day of starting to pump Israeli natural gas from the Leviathan field to Egypt as "a historic moment for celebration" (Steinitz 2020).

Undoubtedly, the words "joyous day" and "historic moment" best describe the Israeli strategic, political, and economic gains resulting from the Israeli gas deal with Egypt, but the question that arises here is: Will Egypt have similar gains? Or rather, can there be strategic and political gains for Cairo resulting from the flow of natural gas from Israel to Egypt? Will the gas coming from Israel be re-exported after liquefaction to bring economic gains that may contribute to achieving a boom for the Egyptian economy, or will the Israeli gas be directed to domestic consumption only?

This article aims to examine the Impact of Gas Discoveries in East Med on Egypt-Israel Relations through reviewing the economic feasibility as well as the strategic and political dimensions of the Israeli gas deal on Egypt, in an attempt to reach accurate and clear answers to the above questions. 


\section{Where will the gas flow from Israel go?}

Before we start discussing the political, strategic, and economic dimensions of the gas deal between Egypt and Israel, there is a pivotal question that we must answer first so that we can assess many elements related to the deal, that is a question about the direction that the gas flowing from Israel will take.

The discovery of the Zohr field represented a major boom for Egypt in the production of natural gas and contributed to achieving self-sufficiency and transforming Egypt from a natural gas importer to an exporter, as Egypt's current production of natural gas exceeds 7 bcf per day (Stevenson 2019), which allowed Egypt to have a surplus that it exports to Jordan and the Edco liquidation plant (Daily News Egypt 2019), and the volume of Egypt's gas production is expected to reach 8 bcf per day in 2021 (Xuequan 2019).

Despite Egypt's achievement of natural gas selfsufficiency, however, a real problem is likely to face Egypt in the future, in light of the dramatic escalation of the volume of Egypt's gas consumption, which means that despite the boom caused by the Zohr field in gas production, within a few years, Egypt will not be able to maintain self-sufficiency of natural gas and will once again turn to import gas to meet the local Egyptian market needs.

Some studies and estimates confirm the end of self-sufficiency in the medium term, that is, after a period ranging between three to five years from now. In mid2018, the Oxford Institute for Energy Studies published a study indicating a slowdown in gas exports in the future compared to increasing local consumption in Egypt (Ouki 2018).

A report issued by CI CAPITAL in mid-2018 included expectations about Egypt's return to importing gas again within a few years (Bahgat2018). Another report issued by Bank BNP Paribas in mid-2019 confirms that Egypt's survival as a natural gas exporter will not last long, expecting that Egypt would return as a net importer of gas at the end of 2021 (Devaux 2019). At the end of 2019, a report was issued by Wood Mackenzie, energy research and consultancy firm, expecting that domestic gas consumption in Egypt would rise by $30 \%$ over the coming two decades, which will lead to a shortage of gas supplies and ending self-sufficiency within only five years (Magdy \&Benmeleh 2019).

When we attempt to answer the question about the direction of the gas coming from Israel, whether it is for re-export after liquefaction or for local consumption, we have to make sure that the answer is not limited to the present moment, but it must cover the timeline extending to 2035 , as the duration of the deal 15 years starting from 2020. Therefore, we should not only consider the current reality of Egypt's natural gas production and its achievement of self-sufficiency but also, we must take into account the expectations of Egypt's gas consumption in the coming years, which confirm that Egypt will return to importing gas once more. Thus, according to the current data and studies related to the future of gas in Egypt, it will be easy to reach a clear and direct answer that natural gas flowing from Israel will be re-exported after liquefaction in the early few years of the deal's lifespan (a period of 3 to 5 years) and that the gas coming from Israel will go to domestic consumption after that (a period of 10 to 12 years).

\section{The economic feasibility of the gas deal}

In the short term, it is assumed that the gas coming from Israel to Egypt will be re-exported abroad after it is liquefied at the Egyptian liquefaction plants in Edco and Damietta and then shipped via LNG tankers to European markets. Consequently, the economic gains here are summarized in two clear elements: the proceeds of gas re-exports to Europe, and the fees for operating Egyptian liquefaction plants. Here, several major questions must be asked to complete, by answering them, the overall picture of the potential economic gains from the gas coming from Israel.

First, can Egypt, through exporting LNG, compete in the European market and reap significant profits?

To answer this question, a set of facts must be listed, including:

a) One of the main problems facing $L N G$ is its high cost compared to regular gas. To understand this, you can imagine the difference between transporting gas to liquefaction plants, liquefying it, shipping it in tankers to Europe, and finally deliquefying it in the importing country; and transporting gas directly through a pipeline to the importing country, which means in short that the cost of liquefied gas is much higher than the cost of regular gas. Therefore, the global markets always prefer transference of gas directly via pipelines, but they resort to the second option, i.e. liquefied natural gas, in case access to the first option is not available. Consequently, transporting gas directly to Europe via pipelines will always remain the first preferred option for the European 


\section{CCenter for Promoting Education and Research (CPER) USA $\underline{w w w . c p e r n e t . o r g ~}$}

market compared to importing liquefied gas (Demir \&Tekir 2017).

b)Russia controls more than a third of the gas imports flowing to the European market, where Russian gas is distinguished not only by being transported directly via pipelines to Europe but also because it (Russian gas) is cheap compared to the global gas prices and compared to its main competitors in the European market, Norway and Algeria, which means that a competition opportunity for the gas coming from Israel with the Russian gas in the European market seems to be a major challenge.

c) $L N G$ prices decreased sharply in 2019, and its prices are likely to continue to decline in 2020 (Feer 2020). It suffices to note that Egypt canceled more than one auction of $L N G$ shipments during August and September 2019 due to the low bid prices. Consequently, the decline in prices of liquefied gas in international markets will have a significant negative impact on the opportunities to export gas coming from Israel.

d)In a few years, most of the gas coming from Israel will go to the Egyptian market for local consumption, which means that the period during which gas coming from Israel can be re-exported abroad will be limited.

Accordingly, if we consider that one of the most important gains from importing gas from Israel is to reexport it after liquidation, it is clear, in light of the above, that the opportunities to re-export gas will face great difficulties.

Second, what are the expected economic gains from gas liquefaction in Egyptian plants?

To answer this question, a set of facts will be listed, including:

a)The ratios of foreign partners in gas liquefaction plants exceed 80\%; where Union Fenosa company owns $80 \%$ of the Damietta plant, while Egypt owns only 20\%; Shell and other partners own $76 \%$ of the Edco plant, while Egypt owns only 24\%. This means that Egypt's share in operating the liquefaction plants is small and does not exceed $25 \%$ of the total proceeds from the liquidation fees.

b)The Damietta plant is still halted, until this moment, due to legal problems with Union Fenosa (a fine of \$2 billion to Union Fenosa), which means that almost half of the capacity of the liquefaction plants in Egypt is halted (Ramsay 2019).

c)The gas liquefaction infrastructure in Egypt is questionable concerning the ability to export the Egyptian gas surplus and re-export the gas coming from Israel and the gas that is supposed to come from Cyprus in the coming years, according to an agreement to transfer Cypriot gas via a shipping line to Egyptian liquefaction plants (Egypt Oil \& Gas 2019).

d)In a few years, most of the gas coming from Israel will be directed to the Egyptian market for local consumption, which means that the period in which these quantities of gas can be exploited through liquefaction and re-export will be extremely short.

Accordingly, if we consider that one of the gains from importing gas from Israel is the operation of the Egyptian liquefaction plants, then it is clear, in light of what is mentioned above, that this view is extremely narrow and that the likely gains according to the facts mentioned above is very limited.

Of course, the fact that Egypt is not expected to reap significant profits from operating the liquefaction plants does not mean that there are no gains from operating the Egyptian liquefaction plants at all. Egypt's possession of liquefaction plants that no other country in the Eastern Mediterranean owns represents an important strategic dimension, and therefore the operation of liquefaction plants brings an interest that cannot be overlooked to Egypt. However, this interest can be only determined in the context of the overall assessment of the deal.

Third, was the promise to drop compensations Egypt had to play behind the gas deal with Israel?

To answer this question, a set of facts will be listed below:

a)In 2012, the contract to export Egyptian gas to Israel, which was signed during the Mubarak era, was canceled, resulting in imposing fines against Egypt estimated at $\$ 1.7$ billion in favor of the Israel Electric Corporation (IEC) and \$288 million in compensation for the East Mediterranean Gas Company(EMG), owner of the Arish-Ashkelon pipeline. Through the gas deal with Israel, Egypt was able to conclude settlements with companies claiming their rights, according to which Egypt would pay $\$ 500$ million to the IEC throughout 8 and a half years instead of $\$ 1.7$ billion. At the 
same time, Egyptian East Gas Company (a subsidiary of EGAS) and its partners (Israeli Delek Drilling-LP, US Noble Energy Inc.) would acquire the largest share of the East Mediterranean Gas Company (EMG), owner and operator of the Arish-Ashkelon pipeline, in exchange for their waiver of compensation at $\$ 288$ million.

b)Undoubtedly, settlement of the fines due on Egypt is one of the gas deal gains, but relying on the settlement policy in exchange for the deal seems to carry a certain amount of risk, especially when we learn that after all these settlements, Thai PTT Company, one of the East Mediterranean Gas Company (EMG), owner and operator of the Arish-Ashkelon pipeline, filed a lawsuit in mid2019 demanding a compensation of $\$ 1$ billion. The logical question that arises, in this case, will be: What kind of deal can Egypt offer to avoid payment of a likely fine to the Thai company. Thus, what the Egyptian government has achieved in reducing compensations due to IEC and EMG might lose its value if the Thai company won its lawsuit against Egypt.

\section{The strategic and political dimensions of the gas deal}

As we explained above, Egypt's gas selfsufficiency will end in a few years; and one of the main gas sources that Egypt relies on for local consumption will be the gas coming from Israel, which simply means that the gas imported from Israel will represent a lifeline for Egypt where there these quantities of gas co will be directed for meeting the needs of Egyptian local market, where heavy industries mainly depend on natural gas, and given that Egypt mainly relies on natural gas for the production of electric energy, where the proportion of natural gas consumed in generating electricity is estimated at $60 \%$ of Egypt's total consumption of natural gas.

In light of the above, here are the most prominent potential threats to Egyptian national security:

a). The fact that Egyptian security is likely to become directly related to Israeli security, as any security threats that may harm the ability of Israel to produce gas will also pose a direct threat to gas supplies coming to Egypt. Consequently, any potential threat to Israel's security does not only affect Israel's interests, but it will also affect Egypt's interests and security, which will motivate Egypt to adopt positions in managing Egyptian foreign policy towards Israeli crises that may go in line with the Israeli policy, whether with Gaza or southern Lebanon or any other regional parties, almost endless crises, to maintain the flow of gas coming from Israel.

b). The danger may not stop there, but Israel can exploit the Egyptian dependence on Israeli gas to blackmail Cairo and influence its political decision in the face of any military crises or operations by Israel in the region through threatening to delay or suspend the supply of natural gas which would give Israel decisive influence in its relationship with Egypt.

c). It suffices here to refer to the orientations of Israeli policy regarding the export of gas, and how it places its national security at the top of its accounts, to see the difference between it and the Egyptian side in this regard. In this respect, Israel is committed to using $60 \%$ of its gas reserves in local consumption to ensure its self-sufficiency of gas until 2040. Through this policy, Israel seeks to achieve a balance between gas export and selfsufficiency in the long run. Whatever the economic gains accrue from gas export, they are in no way equal to the threat posed to selfsufficiency that can put Israel in a position of dependence on gas flowing from neighboring countries, as Israel's priority is to avoid allowing its neighboring countries to possess pressure cards that could pose a threat to its national security in the long run.

\section{East Med pipeline, a potential threat to Egypt}

Israel has repeatedly announced its intention to construct an East Med gas pipeline that will extend to Cyprus, Greece, and Italy to export gas flowing from Israel and Cyprus to European markets through Greece and Italy. Although this project faces technical challenges due to the difficulty of laying gas pipelines in deep waters and the likely high costs (Speranza \& De Lorenzo 2017, pp. 305), Israel is serious in its endeavor to establish the pipeline so that it can turn into a platform for exporting gas to Europe, where Israel, Cyprus, and Greece signed an agreement to construct the pipeline in January 2020 (Tugwell 2020).

Through the construction of the new pipeline, Israel aims to make the most of its gas reserves and look forward to becoming the first gas export platform in the Eastern Mediterranean region. The Israeli gas pipeline is expected to incur significant economic losses to Egypt due to its expected negative impact on Egypt's aspiration 
to be a future platform for gas export to Europe, considering that the new Israeli pipeline will be a source for transporting natural gas directly to European markets more quickly and at less cost compared to the gas coming from Egypt which needs to be liquefied before shipping via tankers to European markets and then deliquefied there again. In short, the likely construction of the Israeli pipeline means ending Egypt's dream to become a platform for exporting natural gas to Europe, and accordingly ending any expected economic gains or political influence based on the flow of Egyptian gas to European markets.

Israel's aspirations regarding its pursuit to construct the new gas pipeline are not limited to merely achieving economic gains, however, Tel Aviv also seeks to achieve several political goals, as Israeli gas flowing to Europe will reduce the influence of Arabs in Europe resulting from the control of Arab oil and gas exports over European markets, which would at the same time lead to increasing Israeli influence there.

\section{Conclusion}

All in all, after reviewing the economic feasibility and the political and strategic dimensions of the gas deal between Egypt and Israel, and after providing an answer to the question about the expected direction of the gas coming from Israel, one can conclude the following:

First, there are potential major threats to Egyptian national security in the future, related to Israel's control of a large part of natural gas supplies to the Egyptian market. These threats should not be absent from any policymaker that understands the nature and dimensions of dealing with Israel, which remains the first strategic enemy of Egypt, even if relations between the two countries appear stable and positive at some point in time. On the other hand, it is easy to realize clearly that the size of Egypt's potential economic gains resulting from the gas deal with Israel is very limited and in no way proportionate to the great risks it poses to Egyptian national security.

Second, there is no accurate official answer to the direction of the gas flowing from Israel until this moment, whether it will go for export to European markets or it will go to domestic consumption. It suffices to point to the inconsistency between the comment of the Egyptian Minister of Energy in which he confirmed that the gas coming from Israel would be directed to export, and a tweet posted on Israel Arabic Twitter account (Israel's official Twitter account in Arabic) to the effect that the Israeli gas exported to Egypt will go to Egyptian local market for electricity production and in industry. However, the fact is that Egypt currently has self-sufficiency and even a surplus in natural gas, that part of Egyptian gas is exported to Jordan. Anyway,in light of the above-mentioned challenges, particularly the low LNG global prices and the likely inability to compete in the European market, the only solution available for the use of gas flowing from Israel at present is to reduce Egypt's production to allow Israeli gas to enter the local Egyptian market.

Third, the gas deal between Egypt and Israel is a stark example that Sisi's policy does not rely on a vision aimed at preserving Egypt's national security or achieving economic interests for the nation, but it rather depends on buildingconsensuses, to appease his international and regional allies and supporters, particularly Israel, which deepens the lack of independence of Egyptian political decision and entrenches dependency and continued loss of Egypt's status, which is apparent in Sisi's decisions that are far from achieving Egypt's interests, but they even negatively affect its national security or remain silent in situations where Egypt's rights and potentials are wasted.

Fourth, the geopolitical impact of the natural gas reserves could lead to many possibilities in the relations between Egypt and Israel. Partnership in the field of gas may lead to further cooperation in the direction of changing the strategic policies of the two countries and the development of the existing relations. On the other hand, competition on the possession and export of natural gas may lead to the creation of tensions between Egypt and Israel, or at least relations remain limited to cooperation for the natural gas file in light of geopolitical difficulties in the region, as is the case with the continued flow of Russian gas to Europe in the wake of the Ukrainian crisis.

\section{Acknowledgment}

Istanbul Aydin University allowed me to finalize this article, and to contribute in the field of the geopolitics of energy, where I hope this article to be useful for all interested in the situation in the Eastern Mediterranean. I especially thank Prof. Dr. RagipKutayKaraca who give me significant notes during the work of this article. 


\section{CCenter for Promoting Education and Research (CPER) USAwww.cpernet.org}

\section{References}

\section{Journal paper}

Aran, A. \&Ginat, R 2014, 'Revisiting Egyptian Foreign Policy towards Israel under Mubarak: From Cold Peace to Strategic Peace'. The Journal of Strategic Studies, vol. 37, no. 4, pp. 556-583.

Demir, N \&Tekir, O 2017, 'Sharing Energy Resources of Eastern Mediterranean: Regional and Global Dynamics', Economic and Environmental Studies, vol. 17, no. 4, pp. 651-674.

Dimou, A 2016, 'East Mediterranean Gas Cooperation and Security Challenges', National Security and The Future, vol. 17, no. 1-2, pp. 99-112.

\section{Books}

Berti, B 2013, 'Israel and the Arab Spring Understanding Attitudes and Responses to the New Middle East', in Vidino L (ed.), The West and the Muslim Brotherhood after the Arab Spring, Foreign Policy Research Institute \& Al Mesbar Studies \& Research Centre, Philadelphia \& Dubai, pp. 130-146.

Speranza, D \& De Lorenzo, D 2017, 'Toward A New Mediterranean Gas Hub?', in Hafner, M \&Tagliapietra, S (ed.), The European Gas Markets: Challenges and opportunities, Palgrave Macmillan, Switzerland, pp. 303-313.

\section{Web pages}

Bahgat, H 2018, Who's buying Israeli gas? A company owned by the General Intelligence Service, Mada, viewed 17 January 2020, <https://madamasr.com/en/2018/10/23/feature/politics/whos-buying-israeli-gas-a-companyowned-by-the-general-intelligence-service/>.

Daily News Egypt 2019, Egypt seeks to increase natural gas production to 8bn scf per day in FY21, viewed 15 June 2020, <https://wwww.dailynewssegypt.com/2019/12/15/egypt-seeks-to-increase-gas-production-to-8bn-scfday-in-fy21/>.

Devaux, P 2019, Egypt: From macroeconomic stabilisation to sustainable growth, Economic Research-BNP Paribas, Jean Lemierre, Paris, France.

Egypt Oil \& Gas 2019, El Sisi Approves Egypt-Cyprus Gas Pipeline, viewed 15 June 2020, <https://egyptoilgas.com/news/el-sisi-approves-egypt-cyprus-gas-pipeline/>.

Feer, J 2020, LNG to test market and infrastructure limits, Petroleum Economist, viewed 6 March 2020, $<$ https://www.petroleum-economist.com/articles/midstream-downstream/lng/2020/lng-to-test-market-andinfrastructure-limits>.

Haaretz 2018, Israeli Natural Gas Giant Signs \$15 Billion Export Deal With Egypt, viewed 15 June 2020, <https://www.haaretz.com/israel-news/business/netanyahu-lauds-israeli-firm-s-15b-gas-deal-with-egypt-1.5828419>.

Magdy, M \&Benmeleh, Y 2019, Israel Boosts Supply in Landmark Natural Gas Deal With Egypt, BNN Bloomberg, viewed 15 March 2020, <https://www.bnnbloomberg.ca/israel-boosts-supply-in-landmark-natural-gasdeal-with-egypt-1.1325066>.

Ouki, M 2018, Egypt - a return to a balanced gas market?, The Oxford Institute for Energy Studies, Oxford, United Kingdom.

Ramsay, P 2019, Egyptian LNG to return to full operation, Petroleum Economist, viewed 8 March 2020, $<$ https://www.petroleum-economist.com/articles/politics-economics/middle-east/2019/egyptian-lng-to-return-to-fulloperation>.

Reuters 2019, Israel to increase gas exports to Egypt, companies say, viewed 18 January 2020, <https://www.reuters.com/article/us-israel-egypt-natgas/israel-to-increase-gas-exports-to-egypt-companies-sayidUSKBN1WH0I6>.

Steinitz, Y 2020. [Twitter]. 15 January. [Accessed 15 July 2020]. Available from:

https://twitter.com/IsraelArabic/status/1217409246737960961?s=19. 
E-ISSN: 2469-6501

VOL: 6, ISSUE: 6

June/2020

DOI: 10.33642/jjbass.v6n6p6

CPER https://ijbassnet.com/

(C) Center for Promoting Education and Research (CPER) USAwww.cpernet.org

Stevenson, P 2019, Egypt Gas Output: More Records, Mees, viewed 12 March 2020, <https://www.mees.com/2019/9/27/news-in-brief/egypt-gas-output-more-records/d0b05d00-e145-11e9-b41a-a3934c16f20f>.

Tugwell, P 2020, Leaders From Israel, Cyprus, Greece Sign EastMed Gas Pipe Deal, Bloomberg, viewed 2June $\quad 2020,<\mathrm{https} / / / \mathrm{www}$.bloomberg.com/news/articles/2020-01-02/leaders-from-israel-to-greece-set-to-sign-eastmed-gaspipe-deal>.

Xuequan, M 2019, Egypt announces new gas discovery in Nile Delta area, Xinhua, viewed 13 March 2020, <http://www.xinhuanet.com/english/2019-07/24/c_138252028.htm>. 